ISSN 1678-3921

Journal homepage: www.embrapa.br/pab

For manuscript submission and journal contents, access: www.scielo.br/pab

\section{Deoxynivalenol content, phenolic compounds, and antioxidant activity of wheat flour after debranning process}

\begin{abstract}
The objective of this work was to evaluate the effect of the debranning process on the deoxynivalenol (DON) content, phenolic compounds, and antioxidant activity of wheat flours, in order to determine which milling technology provides the safest and most nutritional wheat products. Grain samples from the BRS Marcante, BRS Reponte, and BRS 374 wheat (Triticum aestivum) cultivars were used to obtain both whole-wheat and white flours. For whole-wheat, grains were debranned at different times (20 and $40 \mathrm{~s}$ ). The debranning process significantly reduced the DON content in the whole-wheat flours from all cultivars. The DON concentration decreased 22 and $28 \%$ in the 20 and 40 s debranning treatments, respectively, when compared with the treatment without debranning. In addition, phenolic compound content and antioxidant capacity are significantly higher in the whole-wheat flours. The debranning process contributes to the production of safer and healthier foods, by reducing DON content and retaining phenolic compounds and antioxidant activity in whole-wheat flours.
\end{abstract}

Index terms: Triticum aestivum, bioactive compounds, mycotoxins, whole-wheat flour.

\section{Níveis de deoxinivalenol, compostos fenólicos e atividade antioxidante de farinha de trigo após processo de polimento}

\begin{abstract}
Resumo - O objetivo deste trabalho foi avaliar o efeito do processo de polimento nos níveis de deoxinivalenol (DON), nos compostos fenólicos e na atividade antioxidante de farinhas de trigo, para determinar a tecnologia de moagem que fornece os produtos de trigo mais seguros e nutritivos. Amostras de grãos das cultivares de trigo (Triticum aestivum) BRS Marcante, BRS Reponte e BRS 374 foram utilizadas para obter farinhas de trigo integral e branca. Para a farinha integral, os grãos foram submetidos a diferentes períodos $(20$ e 40 s) de polimento. O processo de polimento reduziu significativamente o teor de DON nas farinhas de trigo integral de todas as cultivares. A concentração de DON diminuiu 22 e $28 \%$ nos tratamentos polimento por $20 \mathrm{e} 40 \mathrm{~s}$, respectivamente, quando comparada à do tratamento sem polimento. Além disso, os níveis de compostos fenólicos e a capacidade antioxidante são significativamente maiores nas farinhas de trigo integral. O processo de polimento contribui para a produção de alimentos mais seguros e saudáveis, ao reduzir o teor de DON e conservar os compostos fenólicos e a atividade antioxidante na farinha de trigo integral.
\end{abstract}

Termos para indexação: Triticum aestivum, compostos bioativos, micotoxinas, farinha de trigo integral. 


\section{Introduction}

Wheat (Triticum aestivum L.) is the basic staple crop in temperate zones, being highly demanded in countries under rapid urbanization and industrialization (Shewry $\&$ Hey, 2015). According to these authors, an important source of starch and energy, wheat may also provide components vital or beneficial to health, including proteins, vitamins, dietary fiber, and phytochemicals.

However, during cultivation, wheat can be adversely affected by climatic and geographic conditions, as well as by pathogens, which can lead to diseases, such as Fusarium head blight (FHB), triggered by infection caused by fungi of the genus Fusarium (Del Ponte et al., 2012). Under stress conditions, these microorganisms produce, via their secondary metabolism, mycotoxins that can contaminate finished processed foods due to their resistance to the processing and technological processes to which the grains are subjected (Karlovsky et al., 2016).

Among the mycotoxins occurring in wheat, deoxynivalenol (DON), part of the type B class of trichothecenes, is the most prevalent, being associated with deleterious effects on human health, such as anorexia, weight loss, malnutrition, endocrine dysfunctions, and immunological changes (Stanciu et al., 2015). According to Cheli et al. (2013), the highest concentration of toxins is found in the outer part of the kernel, but the content of DON in the bran is the greatest concern, especially since these parts, which are almost always used for animal feed, are sometimes directly consumed by humans due to their health benefits. The main advantages of consuming whole-wheat products include: improving large bowel function by slowing down digestion and increasing the absorption of carbohydrates and fats; and reducing the risk of developing certain diseases (Vidal et al., 2016).

Although the bran fraction layers are removed by the milling process, they could be preserved to be used as key ingredients (bioactive compounds) for cerealbased foods because of their high nutritional potential (Ciccoritti et al., 2017). These authors highlighted that phenolic compounds have antioxidant capacities, being associated, for example, with a reduction in the risk of chronic diseases related to oxidative stress.

One of the strategies to preserve part of the wheat bran is the debranning process, which gradually removes the outer layers of the grain, allowing the aleurone tissue to remain attached to the endosperm; in conventional milling, the aleurone layer is removed with the bran (Melini et al., 2020). Therefore, the flours obtained by debranning are richer in components commonly found in the grain aleurone (Melini et al., 2020).

Progressive debranning allows discarding the most external layers, reducing contamination risk, but retaining selected fractions enriched in bioactive compounds, such as phenolic compounds (Bordiga et al., 2016). The most external fractions, associated with a greater occurrence of natural and synthetic contaminants, could then be discarded, while the fractions with a low toxicity but a high nutritional value could be added back to the flour or used as a functional ingredient (Sovrani et al., 2012). According to Martini et al. (2015), debranning appears to be a valuable approach for detecting optimum abrasion levels for grain processing, representing the best compromise between nutritional, technological, and hygienic-sanitary characteristics. Ciccoritti et al. (2017), for example, found that the debranning of durum wheat allowed producing pasta with a high content of healthy compounds, minimally affecting initial sensory properties.

Previous studies on common wheat varieties have shown that bioactive compounds are mainly concentrated in the outer layers of the grain and that their distribution within the kernel depends on the classes of nutrients (Sovrani et al., 2012). Therefore, it is important to combine wheat varieties rich in natural bioactive compounds with a grain-processing technology that allows preserving these compounds and producing functional ingredients (Giordano et al., 2017).

The objective of this work was to evaluate the effect of the debranning process on the deoxynivalenol content, phenolic compounds, and antioxidant activity of wheat flours, in order to determine which milling technology provides the safest and most nutritional wheat products.

\section{Materials and Methods}

The used grain samples were obtained in the 2014 crop season from the BRS Marcante, BRS Reponte, and BRS 374 wheat cultivars, naturally contaminated by Fusarium, when grown at the breeding plots of Embrapa Trigo, located in the municipality of Passo Fundo, in the state of Rio Grande do Sul, in Southern Brazil $\left(28^{\circ} 13^{\prime} 30.2^{\prime \prime} \mathrm{S}, 52^{\circ} 24^{\prime} 31.9^{\prime \prime} \mathrm{W}\right.$, at an altitude of

Pesq. agropec. bras., Brasília, v.55, e01851, 2020

DOI: 10.1590/S1678-3921.pab2020.v55.01851 
$683 \mathrm{~m})$. The climate of the region is classified as Cfa, warm and temperate, by Köppen-Geiger (Beck et al., 2018). According to the Brazilian soil classification system, the soil is a Latossolo Vermelho distrófico típico (Santos et al., 2018), i.e., a Oxisol.

The three chosen cultivars represent Brazilian wheat with different technological traits. The BRS Marcante cultivar has a high gluten strength $\left(\mathrm{W}=>220 \times 10^{-4} \mathrm{~J}\right)$ and is moderately resistant to fungal diseases, including FHB. The BRS Reponte cultivar is characterized by intermediate gluten strength $\left(\mathrm{W}=160 \times 10^{-4} \mathrm{~J}\right)$, higher yields, and moderate resistance to FHB. The BRS 374 cultivar presents low gluten strength $\left(\mathrm{W}=123 \times 10^{-4} \mathrm{~J}\right)$ and is susceptible to FHB.

Grain samples of $10,000 \mathrm{~g}$ were selected from each cultivar based on their initial DON concentrations, which had to be above $200 \mu \mathrm{g} \mathrm{kg}^{-1}$. The DON content was analyzed with the AgraQuant enzyme-like immunosorbent assay kit (Romer Labs Division Holding $\mathrm{GmbH}$, Getzersdorf, Austria). The wheat samples were kept at $8^{\circ} \mathrm{C}$, in a cold chamber, before the analyses.

To obtain the whole-wheat flours, grain samples of approximately $50 \mathrm{~g}$ from each cultivar were fed one at a time to the PAZ-1-DTA rice laboratory testing mill (Zaccaria, Limeira, SP, Brazil), previously regulated for each treatment, at two debranning times (20 and $40 \mathrm{~s})$. The debranning process was monitored using a timer, and the samples were weighed before and after the procedure. After each pearling passage, the equipment was thoroughly cleaned by dust aspiration and compressed air to minimize the amount of contamination between experiments. Then, intact grains (not debranned) and the grains after each debranning treatment (20 and $40 \mathrm{~s}$ ) were milled in the Lab Mill 3100 equipment (Perten Instruments, Huddinge, Sweden). The flour fractions were ground to pass through a $0.8-\mathrm{mm}$ sieve. The resulting wholewheat flours were evaluated for DON content, phenolic compounds, antioxidant activity, chemical composition (moisture, protein, and ash), and flour color.

The white flours were obtained by traditional milling. For this, another set of samples from the BRS Marcante, BRS Reponte, and BRS 374 wheat cultivars, of 4,000 $\mathrm{g}$ each, were prepared for milling according to method 26-10.02 of American Association of Cereal Chemists International (AACC International, 2010). The samples were conditioned to $14 \%$ moisture content and milled using the Quadrumat Senior pilot-scale mill (Brabender GmbH \& Co. KG, Duisburg, Germany).

The wheat grain hardness index (GHI) was determined for whole-wheat flour using the XDS near-infrared rapid content analyzer (FOSS Analytical A/S, Hillerød, Denmark). Method 55-31.01, consisting of the single-kernel characterization system, was used for hardness calibration (AACC International, 2010).

For both whole-wheat and white flours, wheat tecnological parameters were assessed. Moisture content was determined by method 44-15.02 (AACC International, 2010). Ash content was obtained according to standard method 104/1 (ICC, 1990) using a muffle furnace at $900^{\circ} \mathrm{C}$ for 2.5 hours. Total nitrogen was determined by method 46-13.01 (AACC International, 2010), in which the crude protein value was calculated by applying a multiplication factor of 5.7. Protein and ash results were expressed as grams per 100 gram on a dry weight basis. The color of the samples was evaluated using the CR-410 Chroma Meter (Konica Minolta: Sensing Global Network, Osaka, Japan) with $\mathrm{D}_{65}$ illuminant and $10^{\circ}$ viewing angle. Color was expressed in the CIEL*a*b* system, considering the $\mathrm{L}^{*}$ (whiteness/darkness), a* (redness/ greenness), and $b^{*}$ (yellowness/blueness) parameters.

DON content was determined by ultra-highperformance liquid chromatography-tandem with triple quadrupole mass spectrometry using the Triple Quad 6500 system (Sciex, Framingham, MA, USA). The extraction, clarification, and derivatization methodology was fully automatized, developed, and validated in-house using the method described by Varga et al. (2012). At the laboratory, the following limits were obtained for the quantification and recovery of DON: $200 \mu \mathrm{g} \mathrm{kg}^{-1}$ and $80 \%$.

In each treatment, the free and bound phenolics were extracted according to the methods presented by Adom \& Liu (2002) and Sosulski et al. (1982), respectively, with slight modifications. The extracts of the free and complex phenolic compounds were used to measure total phenolic content and antioxidant activity by the 2,2-diphenyl-1-picrylhydrazyl hydrate (DPPH) and 2,2'-azino-bis (3-ethylbenzothiazoline-6sulfonic acid) (ABTS) radicals. Both of these assays were previously described in López-Perea et al. (2019).

The analytical determinations of the samples were performed in triplicate, and standard deviations were reported. Means were compared by Tukey's test, at 5\% 
probability, through the analysis of variance using the Statistica, version 7.0, software (Hilbe, 2007).

\section{Results and Discussion}

Debranning did not affect significantly the GHI, except for the BRS 374 cultivar, which showed a significant reduction in hardness after the procedure (Table 1).

In the 20 and $40 \mathrm{~s}$ treatments, the mean debranning levels were 1 and $2 \%$, respectively, representing the grain mass losses for the BRS Marcante and BRS Reponte cultivars. According to the Healthgrain consortium, losses of less than $2 \%$ of the grain and $10 \%$ of the bran, that occur through processing, are allowed in the production of whole-wheat products (van der Kamp et al., 2014). For the BRS 374 cultivar, the debranning level only differed statistically in the $40 \mathrm{~s}$ treatment. The debranning levels observed in the present study were lower than those reported in the literature (Tibola et al., 2019), due to the applied debranning times and sample homogeneity (same cultivar). These procedures guaranteed low starch losses and, at the same time, noticeably reduced contamination by DON (Figure 1). In a previous study, the mean debranned levels reported for commercial wheat samples, composed of a blend of different cultivars, were 4,8 , and $14 \%$ after debranning for 15 , 30, and $60 \mathrm{~s}$, respectively (Tibola et al., 2019).

The moisture content in whole-wheat flours ranged from 11.7 to $12.6 \%$ and was not significantly affected by debranning (Table 1). The white flour presented the highest moisture content probably because it was tempered to $14 \%$ moisture for milling. As expected, the white flour from all cultivars also had a lower ash content. The ash content of the BRS Marcante and BRS 374 cultivars significantly reduced due to the progressive removal of the external layers of the wheat grains by debranning, while that of the BRS Reponte cultivar decreased after debranning, but only differed significantly in the $40 \mathrm{~s}$ treatment. As reported in other studies (De Brier et al., 2015; Ciccoritti et al., 2017), the highest concentration of minerals was observed in the outermost layers of the grains, namely the pericarp and aleurone (Belitz \& Grosch, 1997).

Protein content was significantly lower in the white flours from all cultivars. However, it was not significantly reduced after consecutive debranning steps at 20 and $40 \mathrm{~s}$ (Table 1). Similarly, De Brier

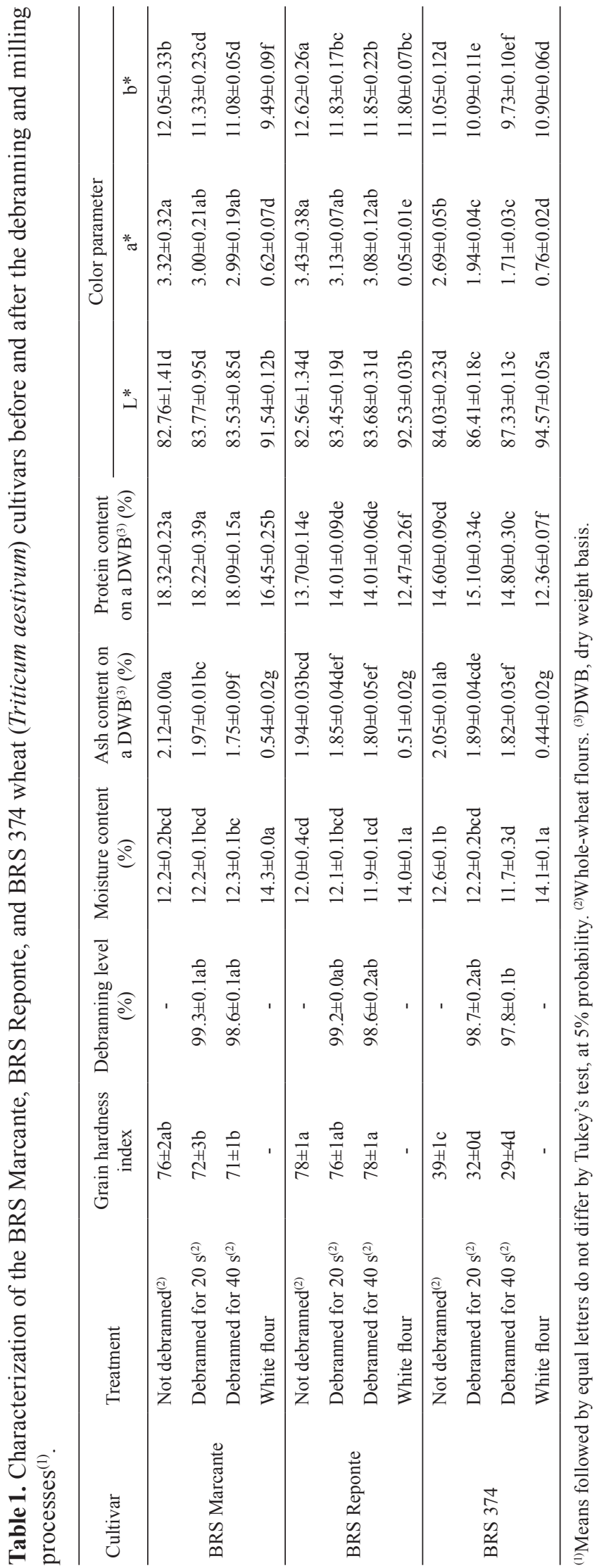


et al. (2015) did not find any significant differences in protein content after the pearling process.

Regarding the CIEL*a*b* system, the $\mathrm{L}^{*}$ parameter, which measures lightness, was significantly higher in the white flours from all cultivars (Table 1). This result was expected since the highest percentage of pigments that give wheat a darker color is located in the outer layers of the grains. After the debranning process, this parameter did not differ significantly for the BRS Marcante and BRS Reponte wheat cultivars. For the BRS 374 cultivar, it increased significantly in the debranned fractions, probably due to the softer grain texture. The $a^{*}$ parameter was reduced in all debranned samples, although it did not differ significantly between the BRS Marcante and BRS Reponte cultivars. As expected, the white flours from all cultivars had a significantly lower a* value. The $b^{*}$ parameter followed the same pattern, showing a significant reduction in all debranned fractions. The lowest value for the $b^{*}$ parameter was observed for the white flour from the BRS Marcante cultivar. Singh \& Singh (2010) analyzed the effect of debranning at the levels of 4 and $8 \%$ in common and durum wheat, respectively, and found that debranning increased the $L^{*}$ value and decreased the $a^{*}$ value at both percentages.

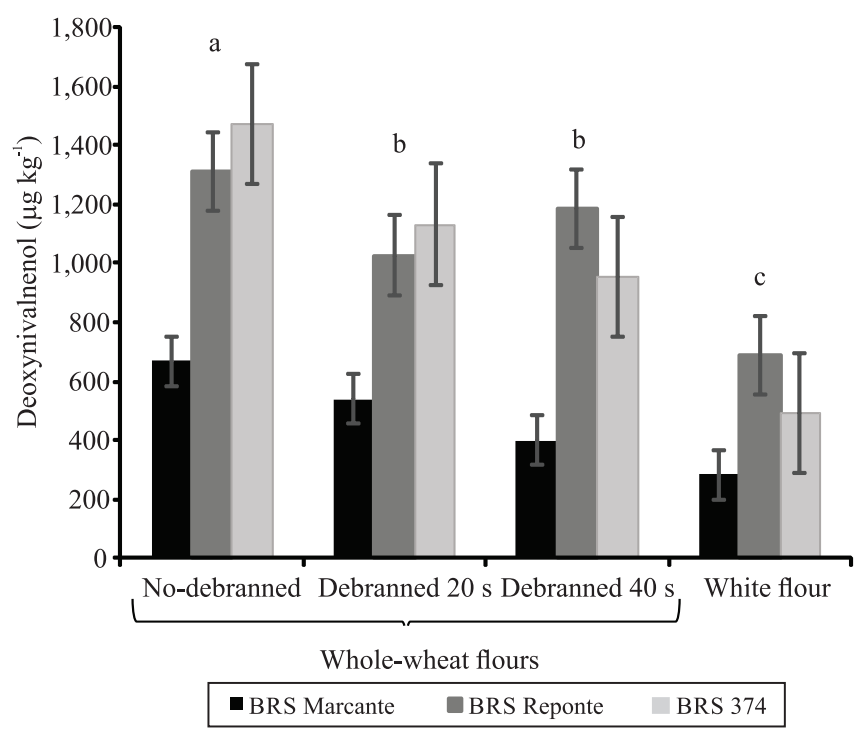

Figure 1. Effect of the debranning process on deoxynivalenol contents in whole-wheat and white flours obtained from the BRS Marcante, BRS Reponte, and BRS 374 wheat (Triticum aestivum) cultivars. Means followed by equal letters do not differ by Tukey's test, at 5\% probability.
The DON content of the white and whole-wheat flours from the BRS Marcante, BRS Reponte, and BRS 374 cultivars is shown in Figure 1. The debranning processes for 20 and $40 \mathrm{~s}$ significantly reduced the DON content in the whole-wheat flours from all wheat cultivars, when compared with the treatment without debranning. Likewise, Ríos et al. (2009) observed that the debranning process in two wheat samples naturally contaminated with Fusarium was more efficient than milling alone to reduce the DON content, regardless of the initial levels of the mycotoxin.

As expected, the lowest DON content was found in the white flour fractions from all cultivars, differing significantly from that of whole-wheat flours (Figure 1). A possible explanation is that, usually, the outer layers (bran) of the wheat grain contain higher levels of Fusarium mycotoxins (Cheli et al., 2013; Tibola et al., 2015).

The BRS Marcante cultivar presented the lowest DON contents. In this cultivar, the DON concentration decreased by 20 and $40 \%$ after debranning for 20 and $40 \mathrm{~s}$, respectively. For the BRS Reponte cultivar, the DON content reduced 22 and $10 \%$ in the 20 and 40 $\mathrm{s}$ treatments, respectively. This unexpected behavior can be attributed to the hardness of the grains (Table 1) and the thickness of the branny layer (Katyal et al., 2019). This result might be due to heterogeneity in mycotoxins distribution in wheat grains and the time of the Fusarium infection (Cheli et al., 2013). The debranning before milling is more efficient when Fusarium infections happen later in the crop season, corresponding to grain filling stage, when the mycotoxins are located more external in the wheat grains layers.

In the BRS 374 cultivar, the debranning times of 20 and $40 \mathrm{~s}$ significantly reduced DON content by 23 and 35\%, respectively. Similarly, Zhao et al. (2019) reported that the DON concentration in wheat decreased approximately $16 \%$ at the debranning ratio of $1.2 \%$ during the on-line milling process, indicating that light debranning prior to milling is an effective method to alleviate DON content.

Although debranning reduced contamination by DON, no significant differences were observed between the treatments 20 and $40 \mathrm{~s}$ in the whole-wheat flours obtained from the BRS Marcante, BRS Reponte, and BRS 374 cultivars (Figure 1). This reduction in DON content due to the debranning process was 
similar to that verified by Sovrani et al. (2012). These authors found that DON content decreased from the external to the internal layers, with $64 \%$ of the total contamination of the kernel in the $0-5$ and $5-10 \%$ fractions, following a biphasic behavior, in which the decrease was high in the first debranning steps and lower in the subsequent ones. Furthermore, Tibola et al. (2019) reported decreases in DON content of 25, 31 , and $31 \%$ at the debranning times of 15,30 , and 60 $\mathrm{s}$, respectively, when compared with non-debranned samples. As for other post-harvest procedures, the effect of debranning and the efficiency of DON reduction are extremely variable, ranging from 15 to $78 \%$ (Cheli et al., 2017). Therefore, combining management strategies is the key to minimize the risk of mycotoxin contamination in wheat products.

In Brazil, the upper limits established for DON contents in whole-wheat flour in 2020 are 1,000 $\mu \mathrm{g} \mathrm{kg}^{-1}$ (Anvisa, 2017). Considering this level, the wheat samples from the BRS Marcante and BRS 374 cultivars after debranning for $40 \mathrm{~s}$ would be within the mycotoxin regulation levels. The DON contents in the wheat samples from the BRS Reponte cultivar, however, remained above the allowed limit, even after the debranning time of $40 \mathrm{~s}$.

Both free and bound phenolics were significantly higher in the whole-wheat flour, compared with the white flour obtained by traditional milling (Table 2), confirming that these compounds are concentrated in the outer layers of the grain (Luthria \& Liu, 2013; Martini et al., 2015). In all cultivars, the content of phenolic compounds, in both the free and cell wallbound form, was significantly higher in the wholewheat flours after debranning for $20 \mathrm{~s}$. In addition, the bound phenolics were more abundant than those in the free form in both the white and whole-wheat flours. This is interesting since, unlike 5 to $10 \%$ of soluble phenolics, bound phenolics cannot be absorbed by the small intestine, passing into the large intestine, where they are fermented by a number of microorganisms and then partially released from the cell wall matrix of the foods (Shahidi \& Yeo, 2016). It should be noted that bound phenolics, such as phenolic acids and flavonoids, show strong bioactivities, including anticancer, anti-inflammation, and cardiovascular disease-ameliorating properties (Shahidi \& Yeo, 2016). Similarly, Adom \& Liu (2002) found that most phenolic compounds in grains exist in bound form: $85 \%$ in corn (Zea mays L.), $75 \%$ in oat (Avena sativa L.) and wheat, and $62 \%$ in rice (Oryza sativa L). Along the same line, Liyana-Pathirana \& Shahidi (2006) stated that the contribution of bound phenolics to total phenolic content was significantly higher than that of the free or esterified fractions in wheat. Among the

Table 2. Total phenolic compounds and antioxidant activity of the free and bound phenolic extracts of wheat (Triticum aestivum) grains subjected to different debranning and milling processes ${ }^{(1)}$.

\begin{tabular}{|c|c|c|c|c|c|c|c|}
\hline \multirow[t]{3}{*}{ Cultivar } & \multirow[t]{3}{*}{ Treatment } & \multirow{2}{*}{\multicolumn{2}{|c|}{ Total phenolic compounds }} & \multicolumn{4}{|c|}{ Antioxidant activity $^{(3)}$} \\
\hline & & & & \multicolumn{2}{|c|}{ DPPH } & \multicolumn{2}{|c|}{ ABTS } \\
\hline & & $\begin{array}{c}\text { Free } \\
\left(\mathrm{mg} \mathrm{GAE} \mathrm{kg}^{-1} \mathrm{DW}\right)\end{array}$ & $\begin{array}{c}\text { Bound } \\
\left(\mathrm{mg} \mathrm{GAE} \mathrm{kg}{ }^{-1} \mathrm{DW}\right)\end{array}$ & $\begin{array}{c}\text { Free } \\
\left(\mu \mathrm{mol} \mathrm{TE} \mathrm{g}^{-1}\right)\end{array}$ & $\begin{array}{c}\text { Bound } \\
\left(\mu \mathrm{mol} \mathrm{TE} \mathrm{g}^{-1}\right)\end{array}$ & $\begin{array}{c}\text { Free } \\
\left(\mu \mathrm{mol} \mathrm{TE} \mathrm{g}^{-1}\right)\end{array}$ & $\begin{array}{c}\text { Bound } \\
\left(\mu \mathrm{mol} \mathrm{TE} \mathrm{g}^{-1}\right)\end{array}$ \\
\hline \multirow{4}{*}{$\begin{array}{l}\text { BRS } \\
\text { Marcante }\end{array}$} & Not debranned ${ }^{(2)}$ & $67.5 \pm 1.2 \mathrm{a}$ & $71.4 \pm 0.0 \mathrm{a}$ & $45.2 \pm 0.2 \mathrm{~d}$ & $39.9 \pm 0.1 \mathrm{~h}$ & $53.7 \pm 0.1 \mathrm{~g}$ & $46.0 \pm 0.2 \mathrm{~g}$ \\
\hline & Debranned for $20 \mathrm{~s}^{(2)}$ & $62.0 \pm 0.0 \mathrm{~b}$ & $65.0 \pm 0.4 \mathrm{~b}$ & $45.7 \pm 0.1 \mathrm{bc}$ & $41.9 \pm 0.2 \mathrm{e}$ & $54.2 \pm 0.1 \mathrm{fg}$ & $47.7 \pm 0.1 \mathrm{f}$ \\
\hline & Debranned for $40 \mathrm{~s}^{(2)}$ & $57.9 \pm 0.4 \mathrm{c}$ & $61.0 \pm 0.3 \mathrm{c}$ & $46.0 \pm 0.2 \mathrm{~b}$ & $44.0 \pm 0.2 \mathrm{c}$ & $55.5 \pm 0.2 \mathrm{bc}$ & $49.4 \pm 0.4 \mathrm{de}$ \\
\hline & White flour & $41.5 \pm 0.8 \mathrm{f}$ & $44.7 \pm 0.1 \mathrm{f}$ & $48.8 \pm 0.1 \mathrm{a}$ & $47.0 \pm 0.1 \mathrm{a}$ & $62.0 \pm 0.2 \mathrm{a}$ & $60.2 \pm 0.1 \mathrm{~b}$ \\
\hline \multirow{4}{*}{$\begin{array}{l}\text { BRS } \\
\text { Reponte }\end{array}$} & Not debranned $^{(2)}$ & $42.1 \pm 0.4 \mathrm{f}$ & $46.3 \pm 0.4 \mathrm{e}$ & $45.6 \pm 0.3 \mathrm{bcd}$ & $40.5 \pm 0.2 \mathrm{~g}$ & $53.8 \pm 0.3 \mathrm{~g}$ & $47.9 \pm 0.2 \mathrm{f}$ \\
\hline & Debranned for $20 \mathrm{~s}^{(2)}$ & $38.6 \pm 0.3 \mathrm{~g}$ & $42.0 \pm 0.4 \mathrm{~g}$ & $46.0 \pm 0.1 \mathrm{~b}$ & $42.8 \pm 0.0 \mathrm{~d}$ & $54.3 \pm 0.1 \mathrm{efg}$ & $49.2 \pm 0.1 \mathrm{e}$ \\
\hline & Debranned for $40 \mathrm{~s}^{(2)}$ & $36.5 \pm 0.1 \mathrm{~h}$ & $38.5 \pm 0.2 \mathrm{~h}$ & $46.0 \pm 0.1 \mathrm{~b}$ & $44.4 \pm 0.0 \mathrm{~b}$ & $55.0 \pm 0.3 \mathrm{~cd}$ & $50.2 \pm 0.1 \mathrm{c}$ \\
\hline & White flour & $30.2 \pm 0.1 \mathrm{j}$ & $32.7 \pm 0.2 \mathrm{j}$ & $48.9 \pm 0.1 \mathrm{a}$ & $47.0 \pm 0.1 \mathrm{a}$ & $62.4 \pm 0.0 \mathrm{a}$ & $61.0 \pm 0.2 \mathrm{a}$ \\
\hline \multirow{4}{*}{ BRS 374} & Not debranned $^{(2)}$ & $48.4 \pm 0.3 \mathrm{~d}$ & $52.4 \pm 0.2 \mathrm{~d}$ & $45.5 \pm 0.0 \mathrm{~cd}$ & $41.0 \pm 0.0 \mathrm{f}$ & $54.7 \pm 0.3 \mathrm{def}$ & $46.5 \pm 0.1 \mathrm{~g}$ \\
\hline & Debranned for $20 \mathrm{~s}^{(2)}$ & $43.9 \pm 0.1 \mathrm{e}$ & $44.7 \pm 0.4 \mathrm{f}$ & $45.9 \pm 0.1 \mathrm{bc}$ & $42.4 \pm 0.1 \mathrm{~d}$ & $54.9 \pm 0.4 \mathrm{cde}$ & $49.8 \pm 0.1 \mathrm{~cd}$ \\
\hline & Debranned for $40 \mathrm{~s}^{(2)}$ & $39.7 \pm 0.2 \mathrm{~g}$ & $41.2 \pm 0.5 \mathrm{~g}$ & $45.8 \pm 0.1 \mathrm{bc}$ & $44.2 \pm 0.2 \mathrm{bc}$ & $56.0 \pm 0.1 \mathrm{~b}$ & $50.0 \pm 0.3 \mathrm{c}$ \\
\hline & White flour & $32.3 \pm 0.1 \mathrm{i}$ & $34.0 \pm 0.1 \mathrm{i}$ & $49.0 \pm 0.1 \mathrm{a}$ & $47.2 \pm 0.1 \mathrm{a}$ & $62.2 \pm 0.2 \mathrm{a}$ & $60.8 \pm 0.1 \mathrm{a}$ \\
\hline
\end{tabular}

${ }^{(1)}$ Means followed by equal letters do not differ by Tukey's test, at $5 \%$ probability. ${ }^{(2)}$ Whole-wheat flours. ${ }^{(3)}$ Antioxidant activity was evaluated by two assays: DPPH, 2,2-diphenyl-1-picrylhydrazyl hydrate; and ABTS, 2,2'-azino-bis (3-ethylbenzothiazoline-6-sulfonic acid). GAE, gallic acid equivalent; and TE, Trolox equivalent. 
non-debranned fractions, the one of BRS Marcante is notable for containing higher free and bound phenolic compounds, differing statistically from those of the other two cultivars (Table 2).

When preparing spaghetti enriched with a debranning fraction of 30:100 w/w durum wheat:semolina, Ciccoritti et al. (2017) found higher values of conjugated and bound phenolic acids - 59.4 and $650 \mathrm{mg}$ per $\mathrm{kg}$ dry matter in functional pasta, respectively, and 21.6 and $27.2 \mathrm{mg}$ per $\mathrm{kg}$ dry matter in the control pasta. A similar trend was observed for conjugated and bound total phenolic contents in the present study.

According to the DPPH assay, the total antioxidant capacity of the free phenolics of non-debranned and debranned whole-wheat flours was 5.7, 4.9, and 5.4\% for the BRS Marcante, BRS Reponte, and BRS 374 cultivars, respectively (Table 2). On average, the whole-wheat flours from all cultivars presented a total antioxidant capacity six-fold greater than that of the white flours. A similar pattern was observed in the ABTS assay, where the total antioxidant capacity of whole-wheat flours was 13-fold greater than that of the white flours. The formation of bound phenolics was also significantly higher in the whole-wheat flours from all cultivars under both assays.

The obtained results are in alignment with those presented in previous studies (Martini et al., 2015; Giordano et al., 2017). Regardless of the variety considered, the bran fraction resulted in a total antioxidant activity 10 and 3-fold higher than that of the refined and whole-grain flours, respectively (Giordano et al., 2017). The total antioxidant capacity of the debranned kernels was also significantly higher than that of the semolina produced from the same durum wheat by traditional milling (Martini et al., 2015).

Although the debranning process is related to the loss of phenolic compounds and to the reduction of antioxidant activity, the $40 \mathrm{~s}$ treatment retained above $80 \%$ of free phenolics and above $75 \%$ of bound phenolics, in comparison with no debranning. Moreover, the DPPH assay showed an antioxidant potential approximately five times greater for the free phenolic extract and two to four times greater for the bound extract in relation to the white flours from all cultivars. This fact indicates that most of these important bioactive compounds are still present for further processing, with great potential for application in functional food formulations, benefiting consumer health. Debranning is a very promising process for the optimal selection of wheat fractions, which can subsequently be used as functional ingredients for the production of healthier and less-refined food products.

\section{Conclusions}

1. The debranning process contributes to the production of safer foods by reducing the deoxynivalenol content of the outermost layers of grains from different wheat (Triticum aestivum) cultivars.

2. Debranning has advantages in relation to conventional milling, including the preservation of beneficial phenolic compounds and antioxidant activity in whole-wheat flours, when compared with white flours.

\section{Acknowledgments}

To Conselho Nacional de Desenvolvimento Científico e Tecnológico (CNPq), for support (project number 473177/2014-5); and to Coordenação de Aperfeiçoamento de Pessoal de Nível Superior (Capes), for partial funding (finance code 88882.156946/2014-01).

\section{References}

AACC International. American Association of Cereal Chemists International. Approved Methods of Analysis. $11^{\text {th }}$ ed. St. Paul, 2010. Method 26-10.02: Experimental milling: introduction, equipment, sample preparation, and tempering; Method 4415.02: Moisture-air-oven methods; Method 46-13.01: Crude Protein-Micro-Kjeldahl Method; Method 55-31.01: Single-kernel characterization system for wheat kernel texture.

ADOM, K.K.; LIU, R.H. Antioxidant activity of grains. Journal of Agricultural and Food Chemistry, v.50, p.6182-6187, 2002. DOI: https://doi.org/10.1021/jf0205099.

ANVISA. Agência Nacional de Vigilância Sanitária. Resolução RDC n ${ }^{\circ} 138$, de 8 de fevereiro de 2017. Altera a Resolução da Diretoria Colegiada - RDC n ${ }^{\circ}$, de 18 de fevereiro de 2011, que dispõe sobre limites máximos tolerados (LMT) para micotoxinas em alimentos, para alterar os LMT da micotoxina deoxinivalenol (DON) em trigo e produtos de trigo prontos para oferta ao consumidor e os prazos para sua aplicação. Diário Oficial da União, 9 fev. 2017. Seção1, p.45.

BECK, H.E.; ZIMMERMANN, N.E.; MCVICAR, T.R.; VERGOPOLAN, N.; BERG, A.; WOOD, E.F. Present and future Köppen-Geiger climate classification maps at $1-\mathrm{km}$ resolution. Scientific Data, v.5, art.180214, 2018. DOI: https://doi.org/10.1038/sdata.2018.214.

BELITZ, H.D.; GROSCH, W. Química de los alimentos. 2.ed. Zaragoza: Editorial Acribi, 1997. 1087p. 
BORDIGA, M.; LOCATELLI, M.; TRAVAGLIA, F.; ARLORIO, M.; REYNERI, A.; BLANDINO, M.; COISSON, J.D. Alkylresorcinol content in whole grains and pearled fractions of wheat and barley. Journal of Cereal Science, v.70, p.38-46, 2016. DOI: https://doi.org/10.1016/j.jcs.2016.05.017.

CHELI, F.; PINOTTI, L.; NOVACCO, M.; OTTOBONI, M.; TRETOLA, M.; DELL'ORTO, V. Mycotoxins in wheat and mitigation measures. In: WANYERA, R.; OWUOCHE, J. (Ed.). Wheat improvement, management and utilization. Croatia: IntechOpen: London, 2017. p.227-251. DOI: https://doi.org/10.5772/67240.

CHELI, F.; PINOTTI, L.; ROSSI, L.; DELL'ORTO, V. Effect of milling procedures on mycotoxin distribution in wheat fractions: a review. LWT - Food Science and Technology, v.54, p.307-314, 2013. DOI: https://doi.org/10.1016/j.lwt.2013.05.040.

CICCORITTI, R.; TADDEI, F.; NICOLETTI, I.; GAZZA, L.; CORRADINI, D.; D'EGIDIO, M.G.; MARTINI, D. Use of bran fractions and debranned kernels for the development of pasta with high nutritional and healthy potential. Food Chemistry, v.225, p.77-86, 2017. DOI: https://doi.org/10.1016/j. foodchem.2017.01.005.

DE BRIER, N.; HEMDANE, S.; DORNEZ, E.; GOMAND, S.V.; DELCOUR, J.A.; COURTIN, C.M. Structure, chemical composition and enzymatic activities of pearlings and bran obtained from pearled wheat (Triticum aestivum L.) by roller milling. Journal of Cereal Science, v.62, p.66-72, 2015. DOI: https://doi.org/10.1016/j.jcs.2014.12.009.

DEL PONTE, E.M.; GARDA-BUFFON, J.; BADIALEFURLONG, E. Deoxynivalenol and nivalenol in commercial wheat grain related to Fusarium head blight epidemics in southern Brazil. Food Chemistry, v.132, p.1087-1091, 2012. DOI: https://doi.org/10.1016/j.foodchem.2011.10.108.

GIORDANO, D.; LOCATELLI, M.; TRAVAGLIA, F.; BORDIGA, M.; REYNERI, A.; COÏSSON, J.D.; BLANDINO, M. Bioactive compound and antioxidant activity distribution in roller-milled and pearled fractions of conventional and pigmented wheat varieties. Food Chemistry, v.233, p.483-491, 2017. DOI: https://doi.org/10.1016/j.foodchem.2017.04.065.

HILBE, J.M. STATISTICA 7: an overview. The American Statistician, v.61, p.91-94, 2007. DOI: https://doi.org/10.1198/000313007X172998.

ICC. International Association for Cereal Science and Technology. Standard Method $n^{\mathbf{0}}$ 104/1: Determination of ash in cereals and cereal products. Vienna, 1990. Approved 1960, revised 1990.

KARLOVSKY, P.; SUMAN, M.; BERTHILLER, F.; DE MEESTER, J.; EISENBRAND, G.; PERRIN, I.; OSWALD, I.P.; SPEIJERS, G.; CHIODINI, A.; RECKER, T.; DUSSORT, P. Impact of food processing and detoxification treatments on mycotoxin contamination. Mycotoxin Research, v.32, p.179-205, 2016. DOI: https://doi.org/10.1007/s12550-016-0257-7.

KATYAL, M.; SINGH, N.; VIRDI, A.S.; KAUR, A.; CHOPRA, N.; AGARWAL, S.; ROY, J.K. Effect of debranning on grains and meal characteristics of different Indian and exotic wheat varieties. Food Research International, v.123, p.327-339, 2019. DOI: https://doi.org/10.1016/j.foodres.2019.04.036.
LIYANA-PATHIRANA, C.M.; SHAHIDI, F. Importance of insoluble-bound phenolics to antioxidant properties of wheat. Journal of Agricultural and Food Chemistry, v.54, p.12561264, 2006. DOI: https://doi.org/10.1021/jf052556h.

LÓPEZ-PEREA, P.; GUZMÁN-ORTIZ, F.A.; ROMÁNGUTIÉRREZ, A.D.; CASTRO-ROSAS, J.; GÓMEZ-ALDAPA, C.A.; RODRÍGUEZ-MARÍN, M.L.; FALFÁN-CORTÉS, R.N.; GONZÁLEZ-OLIVARES, L.G.; TORRUCO-UCO, J.G. Bioactive compounds and antioxidant activity of wheat bran and barley husk in the extracts with different polarity. International Journal of Food Properties, v.22, p.646-658, 2019. DOI: https://doi.org/10.1080/10942912.2019.1600543.

LUTHRIA, D.L.; LIU, K. Localization of phenolic acids and antioxidant activity in sorghum kernels. Journal of Functional Foods, v.5, p.1751-1760, 2013. DOI: https://doi.org/10.1016/j. jff.2013.08.001.

MARTINI, D.; D'EGIDIO, M.G.; NICOLETTI, I.; CORRADINI, D.; TADDEI, F. Effects of durum wheat debranning on total antioxidant capacity and on content and profile of phenolic acids. Journal of Functional Foods, v.17, p.83-92, 2015. DOI: https://doi.org/10.1016/j.jff.2015.04.054.

MELINI, V.; MELINI, F.; ACQUISTUCCI, R. Phenolic compounds and bioaccessibility thereof in functional pasta. Antioxidants, v.9, art.343, 2020. DOI: https://doi.org/10.3390/ antiox 9040343 .

RÍOS, G.; PINSON-GADAIS, L.; ABECASSIS, J.; ZAKHIAROZIS, N.; LULLIEN-PELLERIN, V. Assessment of dehulling efficiency to reduce deoxynivalenol and Fusarium level in durum wheat grains. Journal of Cereal Science, v.49, p.387-392, 2009. DOI: https://doi.org/10.1016/j.jcs.2009.01.003.

SANTOS, H.G. dos; JACOMINE, P.K.T.; ANJOS, L.H.C. dos; OLIVEIRA, V. Á. de; LUMBRERAS, J.F.; COELHO, M.R.; ALMEIDA, J.A. de; ARAÚJO FILHO, J.C. de; OLIVEIRA, J.B. de; CUNHA, T.J.F. Sistema brasileiro de classificação de solos. 5.ed. rev. e ampl. Brasília: Embrapa, 2018.

SHAHIDI, F.; YEO, J. Insoluble-bound phenolics in food. Molecules, v.21, art.1216, 2016. DOI: https://doi.org/10.3390/ molecules21091216.

SHEWRY, P.R.; HEY, S.J. The contribution of wheat to human diet and health. Food and Energy Security, v.4, p.178-202, 2015. DOI: https://doi.org/10.1002/fes3.64.

SINGH, S.; SINGH, N. Effect of debranning on the physicochemical, cooking, pasting and textural properties of common and durum wheat varieties. Food Research International, v.43, p.2277-2283, 2010. DOI: https://doi.org/10.1016/j. foodres.2010.07.016.

SOSULSKI, F.; KRYGIER, K.; HOGGE, L. Free, esterified, and insoluble-bound phenolic acids. 3. Composition of phenolic acids in cereal and potato flours. Journal of Agricultural and Food Chemistry, v.30, p.337-340, 1982. DOI: https://doi.org/10.1021/ jf00110a030.

SOVRANI, V.; BLANDINO, M.; SCARPINO, V.; REYNERI, A.; COÏSSON, J.D.; TRAVAGLIA, F.; LOCATELLI, M.; BORDIGA, M.; MONTELlA, R.; ARLORIO, M. Bioactive compound content, antioxidant activity, deoxynivalenol and

Pesq. agropec. bras., Brasília, v.55, e01851, 2020

DOI: 10.1590/S1678-3921.pab2020.v55.01851 
heavy metal contamination of pearled wheat fractions. Food Chemistry, v.135, p.39-46, 2012. DOI: https://doi.org/10.1016/j. foodchem.2012.04.045.

STANCIU, O.; BANC, R.; COZMA, A.; FILIP, L.; MIERE, D.; MAÑES, J.; LOGHIN, F. Occurrence of Fusarium mycotoxins in wheat from Europe - a review. Acta Universitatis Cibiniensis. Series E: Food Technology, v.19, p.35-60, 2015. DOI: https://doi.org/10.1515/aucft-2015-0005.

TIBOLA, C.S.; FERNANDES, J.M.C.; GUARIENTI, E.M.; NICOLAU, M. Distribution of Fusarium mycotoxins in wheat milling process. Food Control, v.53, p.91-95, 2015. DOI: https://doi.org/10.1016/j.foodcont.2015.01.012.

TIBOLA, C.S.; GUARIENTI, E.M.; DIAS, A.R.G.; NICOLAU, M.; DEVOS, R.J.B.; TEIXEIRA, D.D. Effect of debranning process on deoxynivalenol content in whole-wheat flours. Cereal Chemistry, v.96, p.717-724, 2019. DOI: https://doi.org/10.1002/ cche.10168.
VAN DER KAMP, J.W.; POUTANEN, K.; SEAL, C.J.; RICHARDSON, D.P. The HEALTHGRAIN definition of 'whole grain'. Food \& Nutrition Research, v.58, art.22100, 2014. DOI: https://doi.org/10.3402/fnr.v58.22100.

VARGA, E.; GLAUNER, T.; KÖPPEN, R.; MAYER, K.; SULYOK, M.; SCHUHMACHER, R.; KRSKA, R.; BERTHILLER, F. Stable isotope dilution assay for the accurate determination of mycotoxins in maize by UHPLC-MS/MS. Analytical and Bioanalytical Chemistry, v.402, p.2675-2686, 2012. DOI: https://doi.org/10.1007/s00216-012-5757-5.

VIDAL, A.; SANCHIS, V.; RAMOS, A.J.; MARÍN, S. The fate of deoxynivalenol through wheat processing to food products. Current Opinion in Food Science, v.11, p.34-39, 2016. DOI: https://doi.org/10.1016/j.cofs.2016.09.001.

ZHAO, J.; LIU, X.; WANG, F. DON reduction of wheat grain without compromising the lab-scale milling properties of flour. Grain \& Oil Science and Technology, v.2, p.62-66, 2019. DOI: https://doi.org/10.1016/j.gaost.2019.09.001. 